\title{
Perlindungan Hukum Terhadap Tata Penglolaan Air di Indonesia
}

Galih Puji Mulyono

Galih Puji Mulyono; Fakultas Hukum Universitas Merdeka Malang; Jl. Terusan Raya Dieng No. 62-64;

Malang; Indonesia.

\begin{tabular}{l} 
A R T I C L E I N F O \\
\hline Article history: \\
Received 2019-05-24 \\
Received in revised form \\
2019-06-30 \\
Accepted 2019-07-01 \\
\hline
\end{tabular}

Kata kunci:

Perlindungan Hukum, Tata

Pengelolaan Air, Indonesia.

Keywords:

Legal Protection, Water Manage-

ment, Indonesia.

\section{Citation:}

Mulyono, G. (2019). Perlindungan Hukum Terhadap Tata Penglolaan Air di Indonesia. Jurnal Cakrawala Hukum, 10(1). doi:10.26905/ idjch.v10i1.3292

Corresponding Author:

Galih Puji Mulyono

E-mail address: galihpujimulyono@unmer.ac.id DOI: https://doi.org/10.26905/idjch.v10i1.3292.

\section{Abstrak}

Penelitian ini mengkaji kebijakan perlindungan hukum sumber daya air di Indonesia. Perlindungan hukum terhadap sumber daya air ini penting sebagai aturan dan pedoman tingkah laku manusia sebagaimana tujuan dari adanya hukum untuk mengatur tertib masyarakat. Perkembangan hukum mengenai sumber daya air perlu di perbarui mengikuti perkembangan masyarakat, sehingga terciptanya perlindungan hukum sumber daya air dapat memberikan dampak terhadap pelestarian air di Indonesia. Jenis penelitian hukum dalam penulisan tesis ini adalah normatif (doctrinal). Metode pendekatan yang digunakan adalah a) Pendekatan Undang-Undang; b) Pendekatan Konseptual; c) Pendekatan Perbandingan. Hasil pembahasan berupa peran swasta dalam pengelolaan SDA didasarkan pada asumsi pentingnya pertumbuhan ekonomi melalui mekanisme pasar dalam alokasi air, dan pentingnya peran sektor swasta dalam melakukan investasi yang terkait dengan pengembangan SDA. Inggris merupakan negara yang terkenal akan kehebatannya dalam bidang pengelolaan air. Bahkan inggris menjadi distributor air untuk negara-negara yang kekurangan air seperti Singapura. Pengelolaan air Inggris memang berbeda dengan Indonesia. Pengaturan air Inggris menggunakan sistem privatisasi air.

\begin{abstract}
This study examines the policy of legal protection of water resources in Indonesia. Legal protection of water resources is important as a rule and guidelines for human behavior as the purpose of the law to regulate public order. Legal developments regarding water resources need to be updated following the development of the community, so that the creation of legal protection for water resources can have an impact on water conservation in Indonesia. This type of legal research in writing this thesis is normative (doctrinal). The method used is a) Approach to the Law; b) Conceptual Approach; c) Comparison Approach. The results of the discussion in the form of the role of the private sector in the management of natural resources are based on the assumption of the importance of economic growth through market
\end{abstract}




\section{Perlindungan Hukum terhadap Tata Penglolaan Air di Indonesia}

Galih Puji Mulyono

mechanisms in water allocation, and the importance of the role of the private sector in making investments related to the development of natural resources. England is a country famous for its prowess in the field of water management. Even the UK is a water distributor for countries that lack water such as Singapore. British water management is indeed different from Indonesia. UK water regulation uses a water privatization system.

\section{Latar Belakang}

Hotel berbintang adalah usaha yang menggunakan suatu bangunan atau sebagian bangunan yang disediakan secara khusus dan setiap orang dapat menginap, makan, serta memperoleh pelayanan dan fasilitas lainnya dengan pembayaran dan telah memenuhi persyaratan sebagai hotel berbintang seperti yang telah ditentukan oleh Dinas Pariwisata Daerah (Diparda). Ciri khusus dari hotel adalah mempunyai restoran yang berada di bawah manajemen hotel tersebut. Berbeda halnya dengan hotel tak berbintang yang merupakan usaha yang menggunakan suatu bangunan atau sebagian bangunan yang disediakan secara khusus, dimana setiap orang dapat menginap, makan, serta memperoleh pelayanan dan fasilitas lainnya dengan pembayaran dan belum memenuhi persyaratan sebagai hotel berbintang tetapi telah memenuhi kriteria sebagai hotel melati yang dikeluarkan oleh Dinas Pariwisata Daerah.

Bertolak pada kasus Fave Hotel di Kota Yogyakarta yang pembangunannya merugikan warga daerah sejumlah miliaran. Warga mengaku bahwa sumur mereka mengalami kekeringan sejak hotel tersebut dibangun, padahal sebelumnya tidak pernah mengalami kekeringan. Namun, Pemerintah Yogyakarta melalui Badan Lingkungan Hidup (BLH) justru beragumen bahwa operasional pihak Fave Hotel sudah benar karena dinilai sudah tepat jika mengambil sumber air dalam yang tidak akan mengganggu sumber air dangkal masyarakat (Firdaus, 2014).
Sama halnya dengan kasus di Kota Semarang mengenai hampir sebagian hotel yang tidak memiliki penampungan air hujan maupun sumur resapan air untuk mengatasi banjir agar air hujan tidak langsung masuk selokan. Selain itu pula banyak hotel kapasitas besar maupun kecil menggunakan sumur bor untuk menyedot air bawah tanah (Septiaji, 2018). Sebab, ketersediaan PDAM sejauh ini belum mampu mencukupi kebutuhan air bersih hotel. Selanjutnya hal serupa juga terjadi di Bali tepatnya pada kabupaten Karangasem yang warga sekitar mengalamai kekeringan pada musim kemarau akibat dari alih fungsi lahan dan yang menjadi penyebab utama adalah tata kelola pemanfaatan air yang buruk (Surya, 2011). Pengeboran sumber air yang dilakukan oleh Perusahaan Daerah Air Minum (PDAM) tidak melalui perencanaan yang matang, bahkan pengalirannya tidak mendahulukan warga sekitar tetapi ke sektor-sektor lain seperti hotel.

Berikut perbandingan jumlah hotel pada daerah Yogyakarta, Bali, Malang tersebut:

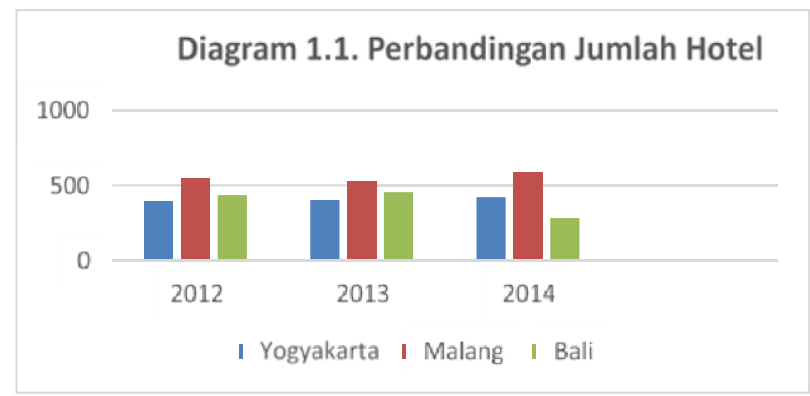

Sumber data: data sekunder diolah, 2018 
Diagram dari tahun 2012-2014 menunjukkan bahwa setiap daerah mengalami kenaikan jumlah hotel dengan interval yang berbeda-beda. Kota Malang mempunyai kenaikan jumlah hotel yang tertinggi diantara ketiga daerah diatas. Sebagaimana telah dijelaskan sebelumnya bahwa daerah Yogyakarta dan Bali mengalami permasalahan pada menyusutnya debit air pada lingkungan sekitar akibat dari pembangunan hotel. Jika Yogyakarta dan Bali yang masih mempunyai jumlah hotel dibawah jumlah hotel di Malang beresiko mengalami pengurangan debit air terhadap lingkungan sekitar, maka tidak menutup kemungkinan bahwa permasalahan serupa juga terjadi pada daerah Malang.

Upaya sistematis dan terpadu tersebut meliputi perencanaan, pemanfaatan, pengendalian, pemeliharaan, pengawasan, dan penegakan hukum. Keberlangsungan perlindungan lingkungan hidup oleh hotel selain menggunakan aspek pemanfaatan berupa pembangungan hotel dengan tujuan fasilitas pariwisata juga harus memperhatikan aspek pemeliharaan dan pengendalian terhadap lingkungan sekitar agar terciptanya suatu keseimbangan. Pasal 26 Undang-Undang Nomor 10 Tahun 2009 Tentang Kepariwisataan menyebutkan bahwa setiap pengusaha pariwisata wajib memelihara lingkungan yang sehat, bersih dan asri, serta memelihara kelestarian lingkungan hidup. Pemeliharaan lingkungan sebagai bentuk aktualisasi menjaga keseimbangan antara lingkungan alam dengan manusia oleh hotel untuk meminimalisir timbulnya dampak negatif terutama terhadap penyusutan debit air.

Berdasarkan latar belakang diatas perlunya upaya kebijakan perlindungan hukum berkaitan dengan sumber daya air di Indonesia agar kejadian kasus tidak terulang kembali dan bagaimana nantinya menjaga sumber daya air di Indonesia tetap lestari. Peraturan perundang-undangan di Indonesia belum melindungi pelestarian sumber daya air untuk dimanfaatkan secara efektif dan efisien.
Di beberapa daerah masih terdapat kekeringan namun terdapat di daerah yang surplus sumber daya air. Karena tidak ada perlindungan hukum terhadap pemanfaatan sumber daya air tersebut mengakibatkan krisis air di beberapa daerah. Krisis air juga di sebabkan oleh manusia itu sendiri dalam pemanfaatan air untuk kelangsungan hidup kurang menyadari pelestarian air. Dapat di lihat dari kurangnya lahan daya serap air karena banyak rumah masyarakat sekarang di paving sehingga air tidak meresap ketanah namun langsung ke sungai dan ke laut sehingga air tidak tersimpan dalam cadangan tanah dan masih banyak kegiatan masyarakat yang tanpa disadari sebagai penyebab krisis sumber daya air di Indonesia.

Oleh karena itu berdasarkan permasalahan di atas, dalam penelitian ini mengkaji kebijakan perlindungan hukum sumber daya air di Indonesia. Perlindungan hukum terhadap sumber daya air ini penting sebagai aturan dan pedoman tingkah laku manusia sebagaimana tujuan dari adanya hukum untuk mengatur tertib masyarakat. Perkembangan hukum mengenai sumber daya air perlu di perbarui mengikuti perkembangan masyarakat, sehingga terciptanya perlindungan hukum sumber daya air dapat memberikan dampak terhadap pelestarian air di Indonesia. Rumusan masalah dalam penalitian ini adalah pelindungan hukum terhadap tata penglolaan air di Indonesia dan Bagaimana kebijakan pelindungan hukum terhadap tata penglolaan air di Indonesia.2..

\section{Metode}

Penelitian hukum terdapat beberapa pendekatan-pendekatan. Dengan pendekatan tersebut, peneliti akan mendapatkan informasi dari berbagai aspek mengenai isu yang sedang dicoba untuk dicari jawabannya (Marzuki, 2014). Penelitian merupakan suatu kegiatan ilmiah yang berkaitan dengan analisa dan konstruksi, yang dilakukan secara metodologis, sistematis dan konsisten. 
Jenis penelitian hukum dalam penulisan tesis ini adalah normatif (doctrinal). Penelitian normatif (doctrinal) adalah suatu prosedur penelitian ilmiah untuk menemukan kebenaran berdasarkan logika keilmuan hukum dari sisi normatif (Ibrahim, 2010). Oleh karena itu, penelitian ini akan mencangkup analisis hukum tertulis (peraturan perundangundangan) yang telah terinventarisir dalam hukum positif Indonesia. Hasil kajian dari norma-norma hukum yang terinventarisir dalam hukum positif membantu dalam menganalisis abstraksi dari norma hukum positif.

Penelitian ini menggunakan beberapa metode pendekatan, metode pendekatan merupakan anak tangga untuk menentukan teori penelitian yang akan dipakai. Pendekatan penelitian dipakai untuk menentukan dari sisi mana obyek penelitian akan dikaji (Syamsudin, 2007). Pendekatan yang digunakan dalam penelitian hukum ini, antara lain: a) Pendekatan Undang-Undang (Statute Aproach); b) Pendekatan Konseptual (Conceptual Approach); c) Pendekatan Perbandingan (Comparative Approach).

\section{Pembahasan}

\section{A. Pelindungan Hukum Terhadap Tata Penglola- an Air Di Indonesia}

Krisis air sering dianggap sebagai crisis of governance (Pasandaran, 2015). Permasalahan krisis air tidak hanya mempersoalkan permasalahan pengaturan pengolaan sumber daya air namun juga struktur sosial politik di dalamnya politik. Ada keterkaitan yang erat antara kekuasaan dan jaringan sosial dalam tata kelola air (Norman, 2012). Oleh karena itu, pengaturan dan pengelolaan air tidak lepas dari peran politik dimana negara mengatur dengan kebijakan dalam rangka pemanfaatan dan penggunaan sumber daya air yang efisien dan efektif. Negara sebagai operator membuat kebijakan berupa peraturan perundang-undangan sebagai saranan mengatur dan mengontrol penggunaan sumber daya air oleh rakyat.
Perkembangan peran kebijakan negara dewasa ini mengalami berbagai permasalah tata kelola air yaitu berkaitan dengan masalah lintas batas (transboundary) yang perlu diatur basis hukumnya baik dalam suatu wilayah sungai yang mencakup berbagai wilayah administrasi atau berbagai negara (Rieu-Clarke, 2013). Oleh karena itu, walaupun Indonesia memiliki rata-rata ketersediaan air permukaan yang relatif besar, sampai 25 kali lipat rata-rata dunia (Sarwoko, 2003), berdasarkan hal tersebut maka pemanfaatan air harus sebaik mungkin dilaksanakan secara efektif dan efisien karena apabila tidak akan menimbulkan permasalahan. Apabila pemanfaatan sumber daya air ini tidak di kontrol maka akan terjadi krisis air atau bahkan banjir bandang. Kejadian tersebut telah terjadi di berbagai wilayah Indonesia (Pasandaran, 2015).

Pentingnya pemanfaatan sumber daya air yang efisien sesuai dengan amanat Konvensi PBB tahun 2002 tentang International Covenant on Economic, Social, and Cultural Rights, Pasal 12.1, dalam kovenan ini disebutkan bahwa air adalah sumber daya alam yang terbatas dan barang publik yang sangat fundamental bagi kehidupan dan kesehatan. Hak mengkonsumsi air merupakan hak bagi setiap manusia dimana mendapatkan pangan yang layak dan terpenuhinya kebutuhan untuk kelangsungan hidupnya adalah salah satu bentuk hak asasi manusia. Amanah Pasal 33 Undang-Undang Dasar Republik Indonesia tahun 1945, menyebutkan bahwa negara menjamin dan melindungi pemanfaatan sumber daya air dan dimanfaatkan sebesar-besarnya untuk kehidupan dan kemakmuran rakyat Indonesia (Pasandaran, 2015).

Secara implisit, pemanfaatan sumber daya air dipandu oleh prinsip efisiensi ekonomi dalam penyusunan pola termasuk prioritas pemanfaatan. Masalah prinsipil yang tidak disentuh dalam konsep undang-undang tersebut adalah masalah keadilan dalam alokasi dan pemanfaatan air yang terkait dengan hakikat sumber daya air dalam suatu wilayah sebagai sumber daya bersama (common pool resources) dan warisan bersama (common heri- 
tage resources). Pemanfaatan sumber daya seperti ini sering menimbulkan gejala eksternalitas baik antartempat atau wilayah maupun antarwaktu. Misalnya, kerusakan di wilayah hulu sungai akan memberikan dampak negatif pada wilayah hilir dan apabila berlanjut akan memberikan dampak negatif terhadap ketersediaan sumber daya air pada generasi yang akan datang, seperti halnya kita dewasa ini merasakan dampak negatif dari perusakan hutan yang terjadi sejak dua atau tiga dasawarsa yang lampau (Pasandaran, 2015).

Memang ini bukan hal yang mudah mengingat pengalaman selama ini menunjukkan bahwa ada kecenderungan pelaku-pelaku swasta yang memperoleh izin pengelolaan sumber daya alam seperti hutan telah memperlakukan sumber daya tersebut secara eksploitatif. Uraian tentang pembiayaan yang juga dicantumkan dalam undangundang tersebut yang mencantumkan sumber-sumber dan cara-cara memperoleh pembiayaan hendaknya tidak saja memperhatikan asas efisiensi tetapi juga hendaknya dipakai untuk mewujudkan asas-asas keadilan yang dicita- citakan.

Mahkamah Konstitusi dalam keputusannya membatalkan keseluruhan Undang-Undang SDA Tahun 2004. Menurut Mahkamah, UU SDA dalam pelaksanaannya telah ditafsirkan secara berbeda sehingga Mahkamah perlu kembali menegaskan pemaknaan bahwa bumi dan air dan kekayaan alam yang terkandung di dalamnya dikuasai oleh negara dan dipergunakan untuk sebesar- besarnya kemakmuran rakyat mengingat air adalah salah satu unsur yang sangat penting dan mendasar dalam hidup dan kehidupan manusia (Bahri, 2015).

Berdasarkan pertimbangan tersebut maka dalam pengusahaan air harus ada pembatasan yang sangat ketat sebagai upaya untuk menjaga kelestarian dan keberlanjutan ketersediaan air bagi kehidupan bangsa yang meliputi (1) pengusahaan atas air tidak boleh mengganggu, mengesampingkan, apalagi meniadakan hak rakyat; (2) negara harus memenuhi hak rakyat atas air mengingat akses rakyat terhadap air adalah salah satu hak asasi tersendiri; (3) kelestarian lingkungan hidup, sebab sebagai salah satu hak asasi manusia harus dijaga mengingat UUD 1945 juga menyatakan bahwa, "setiap orang berhak hidup sejahtera lahir dan batin, bertempat tinggal, dan mendapatkan lingkungan hidup yang baik dan sehat serta berhak memperoleh pelayanan kesehatan"; (4) pengawasan dan pengendalian oleh negara atas air sifatnya mutlak; dan (5) prioritas utama yang diberikan pengusahaan atas air adalah Badan Usaha Milik Negara atau Badan Usaha Milik Daerah. Walaupun demikian Pemerintah masih dimungkinkan untuk memberikan izin kepada usaha swasta untuk melakukan pengusahaan atas air dengan memperhatikan pembatasan-pembatasan tersebut di atas.

Putusan MK adalah prospektif dan tidak retroaktif sehingga seluruh klausul dalam perjanjian yang telah disepakati sebelum ketukan palu pembatalan adalah hal yang beralasan hukum. Dengan demikian, penghormatan kontrak tetap dijalani sembari berharap penyusunan UU SDA yang baru yang mengakomodasi kepentingan perlindungan sebesar-besarnya kemakmuran rakyat.

Keputusan MK bersifat prospektif terutama yang menyangkut perjanjian baik antara swasta dan pemerintah maupun antarpelaku lainnya. Implikasi lainnya yang perlu segera ditindaklanjuti adalah langkah-langkah untuk menyelaraskan peraturan- peraturan yang muncul sebagai tindak lanjut UU SDA dengan pemberlakuan UU No. 11 Tahun 1974 tentang Pengairan sebagai konsekuensi pembatalan UU SDA.

Menurut Sentot Sudarwanto (2015) hal-hal penting mengenai pengelolaan dan pemanfaat sumber daya air yang belum diatur oleh UU No. 11 Tahun 1974 adalah asas pengelolaan dan hak guna air, detail wewenang dan tanggung jawab untuk masing-masing wilayah sungai, empat misi pengelolaan sumber daya air (konservasi, pendayagunaan sumber daya air, pengendalian daya rusak air, dan sistem informasi sumber daya air), 
peran serta masyarakat, pelaksanaan konstruksi, operasi dan pemeliharaan, koordinasi, penyelesaian sengketa, gugatan masyarakat dan organisasi, sanksi pidana yang lebih logis.

Sentot Sudarwanto (2015) mengemukakan Secara teori, dampak dibatalkannya UU SDA akan dirasakan oleh tiga pihak yaitu pemerintah, badan usaha pengelola air, dan masyarakat;

1. Dampak bagi Pemerintah

a. Berimplikasi pada peraturan perundangundangan sebagai aturan pelaksanaan UU SDA tidak berlaku, sehingga sebagai payung hukum diberlakukan kembali UU Pengairan;

b. Negara mempunyai hak menguasai sumber daya air, prioritas utama menguasai atas air diberikan kepada BUMN dan BUMD.

2. Dampak bagi Badan Usaha Pengelola Air

a. Dibatalkannya UU SDA berimplikasi turunan peraturan sebagai peraturan pelaksanaannya menjadi batal sehingga hilangnya payung hukum yang menjadi dasar penerbitan izin pengambilan air bagi Badan Usaha Pengelola Air baik ditingkar pusat maupun daerah;

b. Untuk proses pengusahaan air harus bermitra dengan BUMN atau BUMD di wilayahnya;

c. Akan berdampak pada terhambatnya iklim yang tidak kondusif dan proses investasi yang belum ada kepastian hukumnya untuk mengatur pendirian industri berbasis air di Indonesia.

3. Dampak bagi Masyarakat

a. Dibatalkannya UU SDA akan berdampak positif dalam kehidupan masyarakat secara luas. Semangat masyarakat atas air bisa terpenuhi sesuai landasan konstitusional UUD 1945 Pasal 33 ayat (3);

b. Kekayaan alam berupa air bisa sepenuhnya dimanfaatkan untuk kemakmuran masyarakat dan kesempatan komersialisasi air oleh perusahaan swasta harus diatur dan diawasi secara ketat;
Dengan dibatalkannnya UU SDA tersebut menjadikan perusahaan swasta pengelolaa air tidak mempunyai payung hukum lagi dan membuka kesempatan yang lebar bagi perusahaan air milik negara (PDAM) untuk memberikan pelayanan penyaluran air bersih kepada masyarakat dengan tujuan bukan untuk komersil atau mencari profit, melainkan memenuhi hak masyarakat terhadap air untuk menjamin kesejahteraan masyarakat.

Terhadap hal tersebut tidak serta merta menjadikan izin-izin yang telah dikantongi oleh beberapa perusahaan swasta batal, melaikan pada setiap daerah perusahan swasta masih terus berjalan dengan menggunakan payung hukum yang lama. diambil salah satu, contohnya saja PT Tirta Investama Klaten menggunakan Peraturan Menteri Pertambangan dan Energi sebagai payung hukum untuk pengelolaan air bawah tanah, sedangkan untuk izin pengelolaan air permukaan menggunakan UU Pengairan sebagai payung hukum. Permasalahan izin yang telah dikantongi perusahaan swasta yang dianggap tidak sesuai menambah permasalahan pelik mengenai amburadulnya peraturan perundang-undangan mengenai sumber daya air.

Pasca dinyatakannya UU No. 7 tahun 2004 tentang Sumber Daya Air yang tidak mempunyai kekuatan hukum mengikat dan diberlakukannya kembali UU Nomor 11 tahun 1974 tentang Pengairan (UU Pengairan), berdasarkan Putusan Mahkamah Konstitusi No. 85/PUU-XI/2013, Pemerintah kemudian menetapkan PP Nomor 121 Tahun 2015 tentang Pengusahaan Sumber Daya Air dan PP Nomor 122 Tahun 2015 tentang Sistem Penyediaan Air Minum untuk menjadi peraturan pelaksana dari UU Pengairan.

PP Nomor 121 Tahun 2015 menjelaskan bahwa sumber daya air dikuasai negara dan dipergunakan untuk sebesar-besar kemakmuran rakyat. Hal ini sesuai dengan amanat Pasal 33 ayat (3) UndangUndang Dasar Negara Republik Indonesia Tahun 1945 yang menyatakan "bumi, air, dan kekayaan 
alam yang terkandung di dalamnya dikuasai oleh negara dan dipergunakan untuk sebesar-besar kemakmuran rakyat". Penguasaan negara atas sumber daya air dilakukan dengan tetap mengakui hak ulayat masyarakat hukum adat setempat atas air sepanjang tidak bertentangan dengan kepentingan nasional dan ketentuan peraturan perundangundangan. Penguasaan oleh negara atas air dilakukan dengan melakukan pengaturan dan pengurusan perizinan dan alokasi air untuk menjamin hak setiap orang untuk mendapatkan air bagi pemenuhan kebutuhan pokok sehari-hari.

Pasal 28A Undang-Undang Dasar Negara Republik Indonesia Tahun 1945 menyatakan setiap warga negara bahwa setiap orang berhak untuk hidup serta berhak untuk mempertahankan hidup dan kehidupannya, dalam rangka memenuhi hak untuk hidup serta untuk mempertahankan hidup, negara berkewajiban untuk menjamin pemenuhan hak setiap warga negara, yang salah satunya adalah melalui penyediaan kebutuhan pokok air minum sehari- hari. Hal ini sejalan dengan ketentuan Pasal 33 ayat (2) Undang-Undang Dasar Negara Republik Indonesia Tahun 1945 yang menyatakan bahwa cabang- cabang produksi yang penting bagi negara dan yang menguasai hajat hidup orang banyak dikuasai oleh negara serta ketentuan Pasal 33 ayat (3) Undang- Undang Dasar Negara Republik Indonesia Tahun 1945 yang menyatakan bahwa bumi dan air dan kekayaan alam yang terkandung di dalamnya dikuasai oleh negara dan dipergunakan untuk sebesar-besarnya kemakmuran rakyat.

Pengelolaan Sumber Daya Air, pada tanggal 18 Februari 2015 Mahkamah Konstitusi mengeluarkan Putusan Nomor 85/PUU-XI/ 2013 atas gugatan pengujian materi yang kedua terhadap UndangUndang Nomor 7 Tahun 2004 tentang Sumber Daya Air. Putusan tersebut antara lain menyatakan bahwa Undang-Undang Nomor 7 Tahun 2004 tentang Sumber Daya Air tidak mempunyai kekuatan hukum dan memberlakukan kembali Undang-
Undang Nomor 11 Tahun 1974 tentang Pengairan. Sehubungan dengan hal tersebut, perlu dilakukan pengaturan mengenai Pengusahaan Sumber Daya Air yang sesuai dengan kondisi pada saat ini. Hal ini sejalan dengan Putusan Mahkamah Konstitusi yang menyatakan bahwa salah satu makna penguasaan air oleh Negara adalah melakukan pengaturan (regelendaad).

Prinsip tersebut mengandung arti bahwa di dalam pengelolaan sumber daya air, kegiatan pengusahaan sumber daya air oleh badan usaha swasta merupakan prioritas terakhir, sehingga persyaratan tertentu dan ketat dapat dilaksanakan pengusahaan sumber daya air tidak sekedar merupakan syarat dalam permohonan izin tetapi merupakan bagian dari seluruh aspek dalam penyelenggaraan pengelolaan sumber daya air. Dengan demikian pengaturan mengenai persyaratan tertentu dan ketat harus diatur mulai dari pengaturan penyusunan rencana penyediaan sumber daya air yang merupakan bagian dari rencana pengelolaan sumber daya air, prioritas pemberian izin, prioritas alokasi air, dan pengawasan pelaksanaan kegiatan pengusahaan sumber daya air serta pemberian sanksi dalam rangka penegakan hukum.

Pengaturan terhadap perizinan dan alokasi air diperlukan karena ketersediaan air secara alamiah tidak sebanding dengan jumlah penduduk yang semakin berkembang. Sehubungan dengan hal tersebut, persaingan antara kebutuhan air bagi pemenuhan kebutuhan pokok sehari-hari dengan kebutuhan air untuk penggunaan lainnya, termasuk kegiatan pengusahaan yang memerlukan sumber daya air, di masa yang akan datang akan semakin meningkat. Untuk menjamin pemanfaatan dan pemakaian air yang adil dan merata diperlukan pengaturan perizinan dan alokasi air, baik untuk pemenuhan kebutuhan pokok sehari-hari dan pertanian rakyat serta pengusahaan sumber daya air. Perizinan dalam pengelolaan sumber daya air diselenggarakan dengan maksud untuk mem- 
berikan perlindungan terhadap hak rakyat atas air, pemenuhan kebutuhan para pengguna sumber daya air dan perlindungan terhadap sumber daya air.

Izin pengusahaan sumber daya air yang ditetapkan bukan merupakan izin untuk memiliki atau menguasai air dan/atau sumber air, tetapi hanya terbatas pada pemberian izin oleh pemerintah kepada pemegang izin untuk memperoleh dan mengusahakan sejumlah (kuota) air, daya air dan/atau sumber air sesuai dengan alokasi yang ditetapkan Pemerintah atau Pemerintah Daerah kepada pengguna air. Izin pengusahaan sumber daya air tidak dapat disewakan atau dipindahtangankan baik sebagian atau seluruhnya.

Telah ditentukan PP Nomor 121 Tahun 2015 tentang Pengusahaan Sumber Daya Air sebagai pelaksana dari UU Pengairan, penguasaan sumber daya air dilakukan dengan berpedoman kepada asas usaha bersama dan kekeluargaan, dan bentuk usaha yang memenuhi asas tersebut ialah berupa Koperasi. Walau telah ditentukan bentuk usaha yang memenuhi asas ialah koperasi, Pasal 13 PP PSDA masih memungkinkan pengusahaan sumber daya air dilakukan oleh Badan Usaha Milik Negara, Badan Usaha Milik Daerah, Badan Usaha Milik Desa, Badan Usaha Swasta, Koperasi, Perseorangan, dan kerja sama antar badan usaha.

Pengusahaan sumber daya air oleh badan usaha swasta atau perseorangan.Izin pengusahaan sumber daya air diberikan untuk jangka waktu paling lama 10 (sepuluh) tahun. Masa berlaku izin pengusahaan sumber daya air sebagaimana dimaksud pada ayat (1) ditetapkan oleh menteri yang menyelenggarakan urusan pemerintahan di bidang sumber daya air, gubernur, atau bupati/walikota sesuai dengan kewenangannya. Penetapan masa berlaku dilakukan dengan memperhatikan ketersediaan air, kondisi dan lingkungan sumber air, dan tujuan pengusahaan. Pengusahaan sumber daya air yang memerlukan prasarana dan sarana dengan investasi besar, izin pengusahaan diberikan untuk jangka waktu sesuai dengan perhitungan rencana keuangan investasi.

Izin Pengusahaan Sumber Daya Air diberikan kepada perseorangan atau badan usaha bukan berbentuk badan hukum yang pemilik usahanya berubah, izin batal dengan sendirinya. Pengusahaan sumber daya air yang diberikan kepada badan usaha yang berbentuk badan hukum yang nama badan usahanya berubah, izin batal dengan sendirinya.

Perpanjangan izin pengusahaan sumber daya air yang habis masa berlakunya dapat diperpanjang dengan mengajukan permohonan perpanjangan izin secara tertulis kepada menteri yang menyelenggarakan urusan pemerintahan di bidang sumber daya air, gubernur, atau bupati/ walikota sesuai dengan kewenangannya paling lambat 3 (tiga) bulan sebelum jangka waktu izin berakhir. Jika perpanjangan izin belum diajukan dalam jangka waktu 4 (empat) bulan sebelum jangka waktu izin berakhir, pemberi izin pengusahaan sumber daya air memberitahukan mengenai masa berakhirnya izin. Penetapan keputusan perpanjangan izin diberikan paling lambat 3 (tiga) bulan sejak diterimanya permohonan perpanjangan izin beserta persyaratan lengkap.

Selain PP PSDA, Pemerintah juga menetapkan PP Nomor 122 Tahun 2015 tentang Sistem Penyediaan Air Minum untuk melaksanakan ketentuan Pasal 3, Pasal 7, dan Pasal 10 Undang-Undang Nomor 11 Tahun 1974 serta untuk memenuhi tanggung jawab Negara dalam menjamin pemenuhan hak rakyat atas air minum dan akses terhadap air minum.

Penyelenggaraan SPAM menjadi tanggung jawab Pemerintah Pusat dan/atau Pemerintah Daerah sesuai dengan kewenangannya guna memenuhi kehidupan yang sehat, bersih, dan produktif sesuai dengan ketentuan peraturan perundang-undangan. Dalam rangka melaksanakan penyelenggaraan SPAM maka dibentuk BUMN dan/atau BUMD oleh Pemerintah Pusat atau Pemerintah Daerah se- 
suai dengan kewenangannya. Jika penyelenggaraan SPAM di luar jangkauan pelayanan BUMN atau BUMD, maka Pemerintah Pusat atau Pemerintah Daerah dapat membentuk UPT atau UPTD sesuai dengan kewenangannya yang dilaksanakan sesuai dengan ketentuan peraturan perundang-undangan. Pemerintah Pusat dan Pemerintah Daerah dapat melakukan kerjasama dalam rangka efisiensi dan efektivitas penyelenggaraan SPAM.

Badan Usaha dapat melakukan penyelenggaraan SPAM untuk memenuhi kebutuhan sendiri pada kawasan yang belum terjangkau pelayanan air minum oleh BUMN, BUMD, UPT, dan UPTD. Penyelenggaraan SPAM untuk memenuhi kebutuhan sendiri dilaksanakan untuk memenuhi kebutuhan pokok air minum sehari-hari dan tidak melayani masyarakat umum.

SPAM terhadap unit air baku dan unit produksi, investasi unit distribusi yang selanjutnya dioperasikan dan dikelola oleh BUMN atau BUMD yang bersangkutan, dan investasi teknologi pengoperasian dan pemeliharaan dalam rangka mengupayakan Penyelenggaraan SPAM yang efektif dan efisien dengan mekanisme kontrak berbasis kinerja.

Dibatalkannya UU SDA, maka MK sementara memberlakukan UU Pengairan kembali untuk mengisi kekosongan hukum agar tidak terjadi kekacauan hukum di bidang pengelolaan sumber daya air. Perlu diingat bahwa pemberlakuan ini hanya sementara, sehingga Pemerintah perlu segera meyusun RUU terkait pengelolaan sumber daya air yang sesuai dengan situasi dan kondisi saat ini, yang mengandung unsur asas pengelolaan dan hak guna air, detail wewenang dan tanggung jawab untuk masing-masing wilayah sungai, empat misi pengelolaan sumber daya air (konservasi, pendayagunaan sumber daya air, pengendalian daya rusak air, dan sistem informasi sumber daya air), peran serta masyarakat, pelaksanaan konstruksi, operasi dan pemeliharaan, koordinasi, penyelesaian sengketa, gugatan masyarakat dan organisasi, sanksi pidana yang lebih logis (Sudarwanto, 2015).

UU Pengairan masih memberikan peluang bagi pihak swasta untuk ikut terlibat dalam pengelolaan air. Terlibatnya pihak swasta dalam pengelolaan air akan membuat air memiliki nilai ekonomis yang dapat diperdagangkan, hal ini akan membuat rakyat kehilangan haknya untuk mendapatkan air. Oleh karena itu, dalam penyusunan RUU sumber daya air harusnya tidak melibatkan pihak swasta dalam proses pengelolaan sumber daya air dan penyediaan air minum, karena kalau mengenai modal untuk mengusahakan sumber daya air tidaklah seberat mengusahakan sumber daya minyak dan gas. Pengelolaan air lebih yang lebih sederhana ini harusnya memampukan Pemerintah untuk sepenuhnya menguasai dan mengusahakan sumber daya air untuk selanjutnya didistribusikan kepada rakyat.

\section{B. Kebijakan Pelindungan Hukum Terhadap Tata Penglolaan Air Di Indonesia}

Inggris merupakan negara yang terkenal akan kehebatannya dalam bidang pengelolaan air. Bahkan inggris menjadi distributor air untuk negara-negara yang kekurangan air seperti Singapura. Pengelolaan air Inggris memang berbeda dengan Indonesia. Pengaturan air Inggris menggunakan sistem privatisasi air. Privatisasi air adalah berpindahnya pengelolaan air baik sebagian maupun seluruhnya dari sektor publik kepada sektor swasta (Anonim, 2011). Sehingga segala bentuk pengelolaan air dan penyalurannya dilakukan oleh pihak swasta dengan lebih banyak mengarah pada profit atau pencarian keuntungan oleh pihak swasta. Bentuk privatisasi air Inggris adalah $\mathrm{Di}$ vestiture, sistem privatisasi air dengan pengalihan aset dan operasi baik sebagian ataupun keseluruhan kepada pihak swasta (Anonim, 2011). Berbeda halnya dengan Indonesia yang saat ini masih belum menggunakan sistem privatisasi air yang maksimal karena privatisasi air dipandang negative sebagai 
upaya pencarian profit yang dalam hal ini perusahaan akan menekan biaya pengelolaan produksi untuk mendapatkan keuntungan yang lebih, sedangkan kualitas produksi dan layaranan tidak memenuhi standar yang ada.

Privatisasi air faktanya mempunyai tujuan dan manfaat yang bagus jika diikuti dengan regulasi yang memadai dari pihak pemerintah, karena pada era ini semakin banyak penggunaan dan pengelolaan air yang dilakukan oleh perseorangan dan cenderung ingin menguasai sumber daya alam dengan hak kepemilikan pribadi serta digunakan untuk dirinya seorang. Salah satu tujuan yang ingin dicapai melalui privatisasi menurut Rian Nugroho adalah memberikan kontribusi finansial kepada negara dan Badan Usaha, mempercepat penerapan prinsip-prinsip Good Corporate Governance, serta membuka akses ke pasar internasional, dan alih teknologi serta transfer best practice kepada Badan Usaha.

Pengaturan kebijakan air yang baik sangat diperlukan dalam langkah privatisasi air, sehingga nantinya tidak akan menimbulkan kerugian terhadap negara yang mempraktekannya, dalam hal ini regulasi pemerintah sangatlah berperan penting dalam pembatasan penerapan air, seperti yang dilakukan oleh Inggris. Berikut tabel perbandingan antara regulasi air antara Inggris dengan Indonesia;
Seperti yang telah dijelaskan sebelumnya bahwa Inggris menggunakan sistem privatisasi air Divestiture, sehingga segala utilisasi air dilakukan oleh swasta dengan kepemilikan dan investasi modal yang bersifat privat, dengan regulasi yang mengikat penuh dari pemerintah. Terhadap regulasinya pemerintah Inggris memberikan persyaratan bagi setiap perusahaan swasta yang ingin mendapatkan lisensi untuk utilisasi air secara ketat dengan melakukan konsultasi terlebih dahulu untuk mendapatkan izin dari Kementrian yang bersangkutan. Izin tersebut termasuk pertanggungjawaban perusahaan terhadap pemeberdayaan lingkungan sekitar.

Tidak hanya mengenai beberapa persyaratan yang harus dipenuhi oleh perusahaan air, terdapat berbagai tanggungjawab yang menjadi beban tersendiri bagi perusahaan, berupa penyediaan sarana dan prasarana dalam utilisasi air yaitu berupa pipa air bersih, pengelolaan limbah rumah tangga (kotoran) dengan penyaluran pipa air kotor tersendiri yang berlisensi, serta pemberdayaan sumber daya air (rencana untuk mengatasi kekeringan sejak dini), mengatasi permasalahan banjir. Terhadap sistem tersebut maka perusahaan akan menarik retribusi penyaluran air bersih dan penyaluran air kotor secara terpisah. Penyaluran air kotor tersebut akan diolah terlebih dahulu, sehingga

\begin{tabular}{|c|c|c|}
\hline INDIKATOR & UU AIR INDONESIA & UU AIR INGGRIS \\
\hline Pengelolan air & $\begin{array}{l}\text { Publik, Swasta, Kelompok } \\
\text { Masyarakat (adat) }\end{array}$ & Privat \\
\hline Privatisasi air & $\begin{array}{l}\text { Belum diterapkan sepenuhnya serta tidak } \\
\text { adanya regulasi mengenai privatisasi air } \\
\text { semenjak UU No. } 7 \text { Tahun } 2004 \\
\text { dihapuskan. }\end{array}$ & $\begin{array}{l}\text { Penerapan sepenuhnya yang diatur oleh } \\
\text { regulasi pemerintah yaitu Water } \\
\text { Industry Act } 1991 \text { (WAI) jo Water Act } \\
2014\end{array}$ \\
\hline Kepemilikan & Publik & Privat \\
\hline Investasi Modal & Swasta & Privat \\
\hline Penetapan Tarif Air & $\begin{array}{l}\text { Penetapan tarif air di Indonesia tergantung } \\
\text { pada kebijakan pemerintah pusat dan } \\
\text { kebijakan setiap daerah, sehingga setiap } \\
\text { daerah mempunyai variasi yang berbeda- } \\
\text { beda (PDAM). }\end{array}$ & $\begin{array}{l}\text { Penetapan tarif air dikontrol oleh badan } \\
\text { OFWAT (office of water service), } \\
\text { sehingga kenaikan atau penurunan tarif } \\
\text { air pada pihak swasta berdasarkan } \\
\text { kebijakan OFWAT. }\end{array}$ \\
\hline
\end{tabular}

Data ini diambil dari berbagai sumber 


\section{Jurnal Cakrawala Hukum, Volume 10 No. 1 Juni 2019}

ISSN PRINT 2356-4962 ISSN ONLINE 2598-6538

tidak mencemari lingkungan terutama sungai. Terhadap besar tarif tersebut ditentukan oleh OFWAT (office of water service) dengan penentuannya yang tidak menggunakan volumetrik melainkan berdasarkan pada nilai property (besar rumah). Sehingga dalam hal ini, masyarakat dengan tingkat ekonomi tinggi akan menutupi pembayaran tarif pada masyarakat ekonomi rendah.

Mengenai segala kerusakan terhadap pipa atau saluran drainase menjadi tanggungjawab pihak perusahaan sepenuhnya dengan sistem pemberian asuransi pada setiap pelanggan. Jika perusahaan mengalami kebangkrutan maka pemerintah inggris akan melindungi konsumen untuk dipindahkan dan memindahkannya ke perusahaan lainnya atau terhadap perusahaan tersebut akan dilakukan merger.

Kualitas pelayanan dan air bersih menjadi prioritas utama dari Negara Inggris. Sehingga untuk mengotrol kinera dari pihak swasta pemerintah menyediakan layanan keluhan terhadap kualitas air. Dukungan untuk konsumen rumah tangga dan bisnis juga tersedia dari Dewan Konsumen untuk Air (CCWater). CCWater mewakili konsumen air dan pembuangan limbah di Inggris dan Wales dan menerima keluhan yang belum terselesaikan (GOV.UK, 2015). Jika perusahaan kedapatan memberikan pelayanan air yang tidak memadai, maka perusahaan sendiri yang harus bertanggungjawab dan memberikan kompensasi kepada pelanggan.

Berbeda halnya dengan Indonesia yang pengaturan air baik air tanah maupun air permukaan masih dilakukan oleh BUMN dan PDAM yang dalam hal ini belum semua wilayah terjangkau karena membengkaknya anggaran yang harus dikeluarkan dan diambil melalui APBN serta pemasalahan utama yang dihadapi saat ini adalah dihapusnya Undang-Undang Nomor 7 Tahun 2004 yang didalamnya terdapat peraturan mengenai privatisasi air yang dianggap negatif oleh masyarakat maupun kalangan individual lainnya.
Kepemilikan air dan pengelolaan air di Indonesia terkesan tumpang tindih karena tidak dapat dipungkiri bahwa Indonesia negara pluralistik yang masih mengakui adanya hak ulayat terhadap penggunaan air. Sehingga tata kelola penggunaan air di Indonesia masih terkesan amburadul, yang membolehkan bebarapa individu atau kelompok masyarakat serta pihak badan usaha menggunakan air tanah (untuk keperluannya sendiri) berdasarkan izin pemerintah pusat ataupun pemerintah daerah yang dalam hal ini pun setiap daerah mempunyai kebijakan masing-masing. Sehingga mengakibatkan pemerintah tidak dapat mengontrol debit air yang digunakan pada setiap kegiatan yang seringkali menimbulkan masalah kekeringan dikemudian hari.

Permasalahan lainnya, tidak semua daerah di Indonesia melakukan pengelolaan limbah kotoran rumah tangga, kebanyakan kotoran limbah rumah tangga dialirkan menuju sungai dan menyebabkan sungai menjadi tercemar. Ditambah pula dengan sistem drainase Indonesia yang sangat buruk mengakibatkan seringnya terjadi banjir pada beberapa daerah. Sehingga pengelolaan air tidak berjalan secara efektif dan efesien yang berdampak pada kekeringan saat musim kemarau. Tarif air yang ditetapkan pun cenderung mengalami kenaikan yang dihitung berdasarkan volume penggunaan air.

\section{Simpulan}

Tata kelola air di Indonesia sebagaian besar diatur untuk kepentingan masyarakat petani dikarenakan pemanfaatan air untuk petani sebagai pemanfaatan irigasi pengairan. Pengaturan pengelolaan air di Indonesia belum di atur secara tegas. Oleh karena itu, perlu diperjelas melalui peraturan pelaksanaan UU SDA dan khususnya Kebijakan Nasional Sumber Daya Air adalah perlunya instrumen kebijakan yang sifatnya inklusif yang memungkinkan kelompok miskin terjamin ketersediaan airnya. Namun, Mahkamah Konstitusi dalam 
keputusannya membatalkan keseluruhan UndangUndang SDA Tahun 2004. Pengusahaan air harus ada pembatasan yang sangat ketat sebagai upaya untuk menjaga kelestarian dan keberlanjutan ketersediaan air bagi kehidupan bangsa.

Inggris merupakan negara yang terkenal akan kehebatannya dalam bidang pengelolaan air. Bahkan inggris menjadi distributor air untuk negaranegara yang kekurangan air seperti Singapura. Pengelolaan air Inggris memang berbeda dengan Indonesia. Pengaturan air Inggris menggunakan sistem privatisasi air. Kualitas pelayanan dan air bersih menjadi prioritas utama dari Negara Inggris. Sehingga untuk mengotrol kinerja dari pihak swasta pemerintah menyediakan layanan keluhan terhadap kualitas air. Dukungan untuk konsumen rumah tangga dan bisnis juga tersedia dari Dewan Konsumen untuk Air (CCWater). CCWater mewakili konsumen air dan pembuangan limbah di Inggris dan Wales dan menerima keluhan yang belum terselesaikan. Jika perusahaan kedapatan memberikan pelayanan air yang tidak memadai, maka perusahaan sendiri yang harus bertanggungjawab dan memberikan kompensasi kepada pelanggan.

\section{Daftar pustaka}

Anonim. 2011. Privatisasi Air. http://www.kruha.org/ page/id/dinamic_detil/11/101/Privatisasi_ Air/Privatisasi_Air.html. diakses pada tanggal 2 Juli 2018.

Bahri S. 2015. Memoar Hukum Sumber Daya Air Pasca Pembatalan oleh Mahkamah Konstitusi. Jakarta. Saresehan Terbatas JSDA Indonesia. Hotel Bidakara.

Firdaus. 2014. Sumur Kering Warga Jogja Aksi Mandi Tanah di Depan Hotel. https://regional.kompas.com/ $\mathrm{read} / 2014 / 08 / 06 / 16225191 /$ Sumur.Kering. Warga.Jogja.Aksi.Mand.Tanah.di.Depan.Hotel. diakses pada tanggal 15 Mei 2018.
GOV.UK. 2015. Policy Paper 2010 to 2015 Government Policy: Water Industry. https://www.gov.uk/government/publications/2010-to-2015-governmentpolicy-water-industry/2010-to-2015-governmentpolicy-water-industry. diakses pada tanggal 27 Juni 2018.

Ibrahim, Johnny. 2010. Teori dan Metode Penelitian Normatif. Malang. Bayumedia Publishing.

Marzuki, Peter Mahmud. 2014. Penelitian Hukum. Jakarta. Kencana Prenada Media.

Norman, E.S., K. Bakker, and C. Cook. 2012. Introduction to the themed section: water governance and the politics of scale. Journal Water Alternatives. V. 5 (1).

Pasandaran, Effendi. 2015. Menyoroti Sejarah Perkembangan Undang-Undang Tentang Air Pengairan dan Sumber Daya Air, Jurnal Forum Penelitian Agro Ekonomi. Vol. 33 No. 1, Juli 2015.

Rieu-Clarke, A. and C. Spray. 2013. Ecosystem Services and International Water Law: towards A More Effective Determination and Implementation of Equity? J. PER, Volume 16 No. 2. http:dx.doi.org/ 10.4314/pelj.v16i2.3.

Sarwoko, A. dan I. Anshori. 2003. Keterpaduan Pengelolaan SDA untuk Pendayagunaan yang Berkelanjutan. Jakarta. Makalah Seminar Menuju Pengelolaan Air yang Berkelanjutan.

Septiadi. 2018. Pemkot Tak Batasi Perizinan Baru. https:// radar.jawapos.com/radarsemarang/read/2018/ 03/13/56753/pemkot-tak-batasi-perizinan-hotelbaru. diakses pada tanggal 20 Mei 2018.

Sudarwanto, AL. Sentot. 2015. Dampak Dibatalkannya Undang-Undang Nomor 7 Tahun 2004 Tentang Sumber Daya Air Terhadap Manajemen Air untuk Kesejahteraan Masyaraka. Junal Yustisia. Vol. 4 No. 2 Mei - Agustus 2015.

Surya. 2011. Bali Terancam Krisis Air Bersih. http:// bali.tribunnews.com/2011/09/29/baliterancam-krisis-air-bersih. diakses pada tanggal 20 Mei 2018.

Syamsudin, M. 2007. Operasionalisasi Penelitian Hukum. Jakarta. Raja Grafindo Persada. 